\title{
"Internet + " and infrastructure construction financing under the background of the Belt and Road
}

\author{
Yanying Zhang ${ }^{\mathrm{a}, *}$, Qian Yu \\ School of Law and Economics, Wu Han University of Science and Technology, Wuhan, Hubei, \\ China \\ a1175143700@qq.com
}

Keywords: Internet +, Infrastructure construction, Financing scale, Financing gap

\begin{abstract}
Internet was born in 1969, now it has infiltrated every aspect of people's life, The development of the Belt and Road is also inseparable from the Internet. Since "The Belt and Road" was put forward in 2013, on the one hand, it has made many achievements, such as Gigan Bernini Bridge, Tau road, Kuala Lumpur subway, Philippines route and so on. On the other hand, there were some problems in infrastructure construction fiancing also, such as the channels of financing was limited, financing demand was difficult to meet and the gap between actual financing and ideal financing was huge. Combining the Internet with infrastructure financing may be a shortcut to infrastructure financing of the countries along the Belt and Road. We used comparative analysis and case analysis by querying the National Statistical Yearbook, the network of the Belt and Road and combining the statistical data and research reports of authoritative organizations (such as the World Bank and $\mathrm{ADB}$ ) to expound the current situation, existing problems and the reasons, estimate the scale of financing and put forward how to solve these difficulties by "Internet + ", designed to make people deeply understand this issue, and contribute to the resolution of related issues.
\end{abstract}

\section{Introduction}

Since building the "Silk Road Economic Belt" was proposed by Xi Jinping when he gave the speech in Kazakhstan on September 2013, The Belt and Road has developed rapidly with the support of the state. So far, six silk roads including the ground, sea, air, energy, electricity, information have developed together and achieved great success. Infrastructure construction and financing which can't be neglected, is proportional to economic development, their relevance up to 83.8\% in regression analysis [1]. The problems,many countries along the Belt and Road facing a shortage of infrastructure funds, need to be solved urgently, While relating research is little, there are only 7 journals containing the keywords of "The Belt and Road", "Infrastructure", "Financing" in CNKI.

This report uses the comparative analysis and case analysis to analyse the situation of infrastructure financing along the line by querying the National Statistical Yearbook, The network of the Belt and Road and combining the statistical data and research reports of authoritative organizations (such as the World Bank and ADB). Designed to make people understand this 
problem deeply, and give a hand to solve. This report will benifit solving this problem, mobilize various subjects to join infrastructure financing, run it long. In addition, the scale-estimating of financing have a reference for some countries.

\section{Current Situation of Infrastructure Construction Financing}

\subsection{The Amount of Financing Grows Continuously and Internal and External Investment Balance is Different}

The volume of infrastructure financing grow continuously, but there are also different internal and external investment problems among different countries. Take China and India for example, in 2010-2015, curve of China using foreign direct investement is flat, while India is more steep; China using foreign direct investment curve is steep, but India is more gentle (Figure 1, Figure 2).

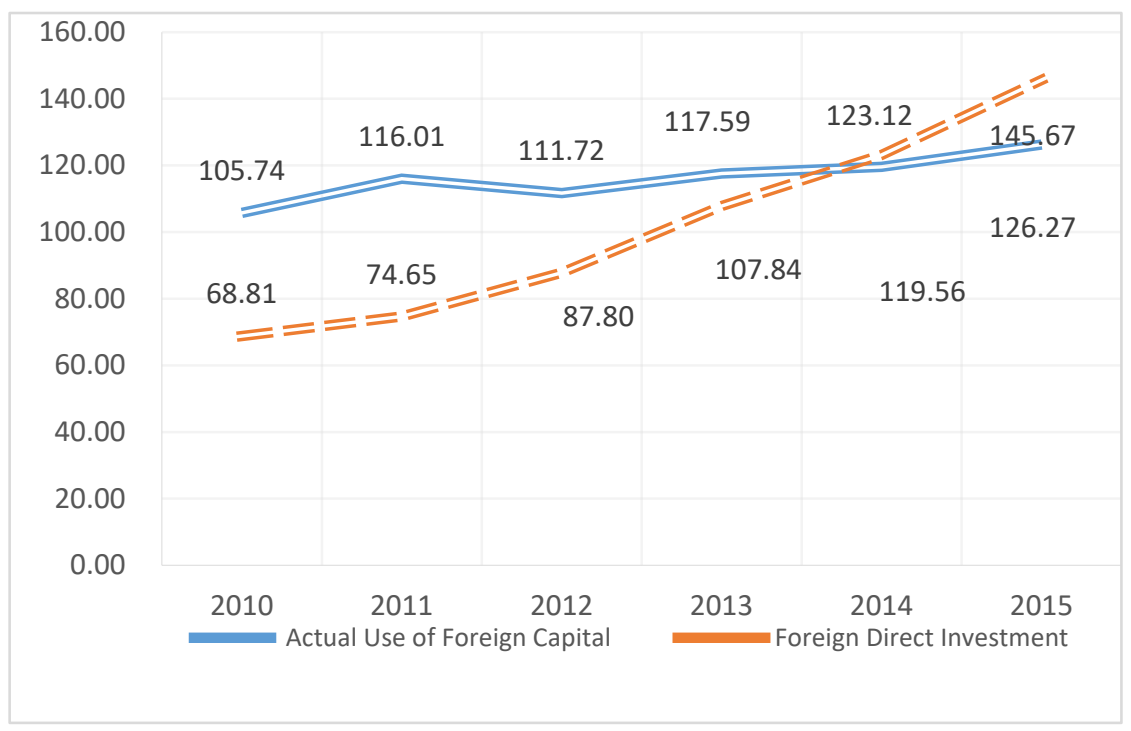

Figure 1: A Comparison of Domestic and Foreign Investment in China (¥hundred million).

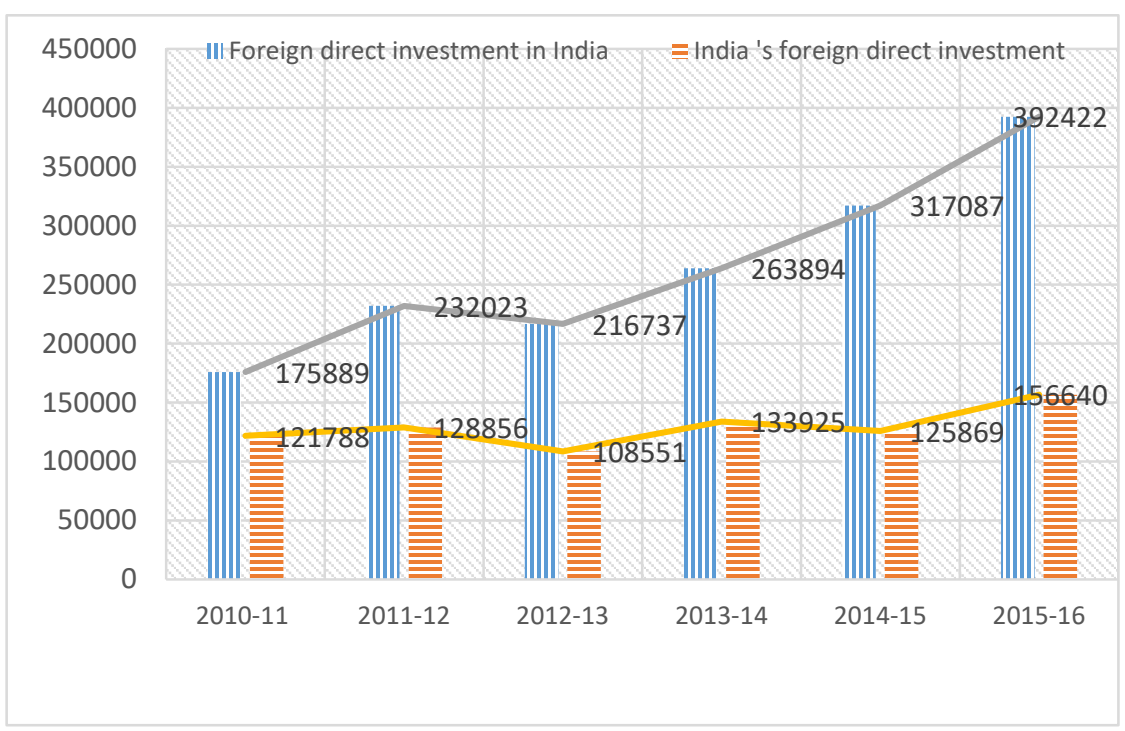

Figure 2 ndia 's international investment(₹billion). 


\subsection{Most of the Financing Channels are Domestic with Little Amount of Foreign Financing}

There are three mainly provider for infrastructure funds: domestic, Hong Kong/Macao/Taiwan and foreign. There number of investment in China's education is 772.32 billion yuan in 2015, accounting for $99.39 \%$ of domestic capital, while foreign investment accounted for only $0.20 \%$. The situation of water conservancy and other four core infrastructure is same(Figure 3, Figure 4), absolutely, China's infrastructure funds are mainly from the domestic.

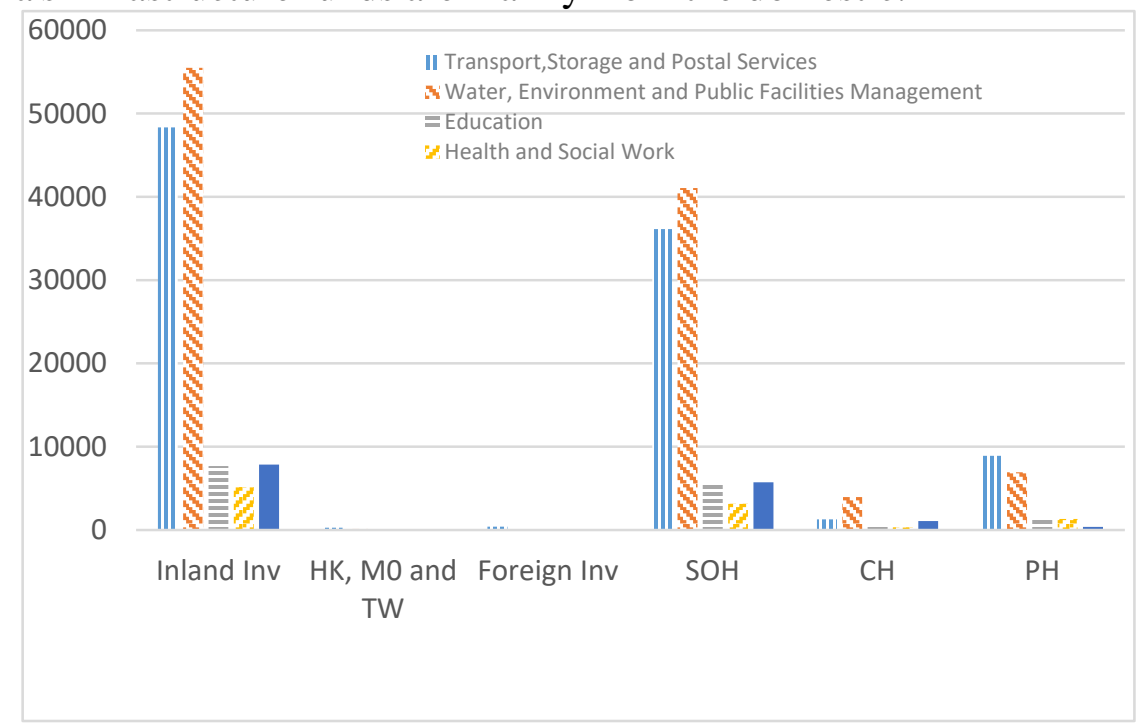

Figure 3 Partial Infrastructure Financing Situation (¥hundred million).

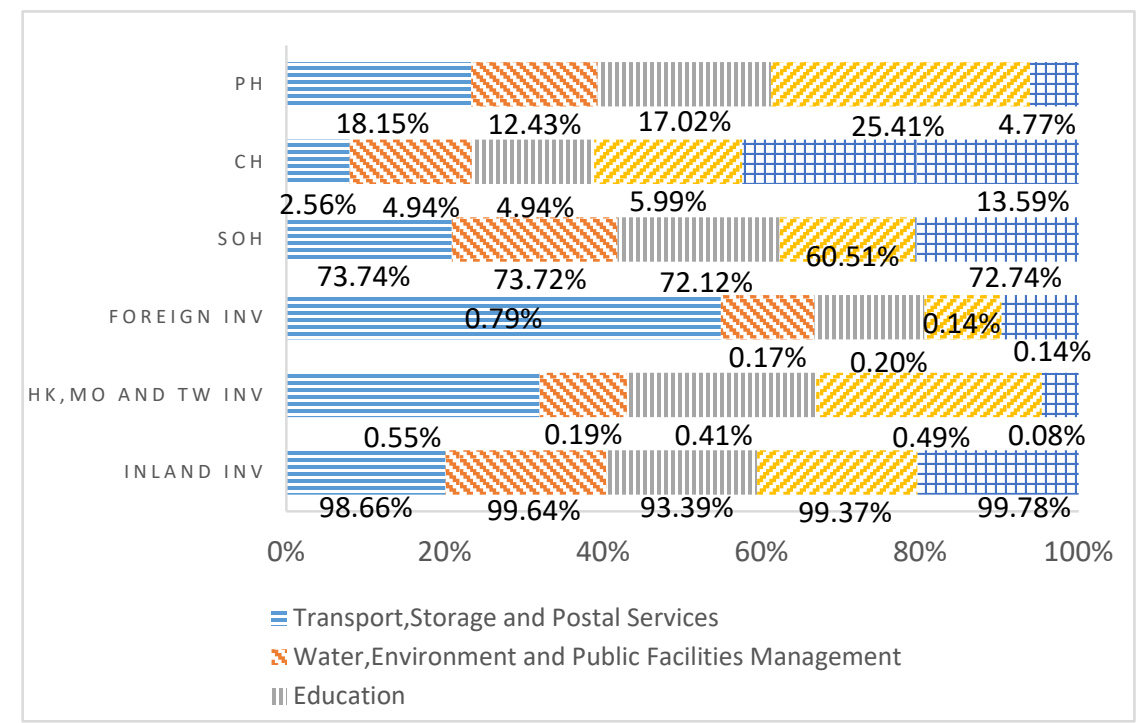

Figure 4 China 's infrastructure investment as\% of Total in 2015.

\subsection{Majorities of Funds are Provided by State and the Private Sector'S Investment is Little}

From the nature of the input subject, there are three types of investment: state-owned, collective and private holdings, the most proportion was accounted for state-owned, private sector's proportion is very small. In 2015, education investment's proportion of state-owned holdings and collective holdings each accounted for $72.12 \%$ and $4.94 \%$ for total, while private holdings only 
accounted for $17.02 \%$, the minimum proportion of private sector investment was only $4.77 \%$ for other four core infrastructure.

According to the data of World Bank in 2016, the Indonesian's infrastructure funds are mainly from the government and state-owned enterprises, the private sector investment is little. Although the share of government and state-owned enterprises investment's proportion had a slight decrease in 2010-2015, it's still around 90\%, while private sector investment remained at only about $10 \%$ in five years (Figure 5).

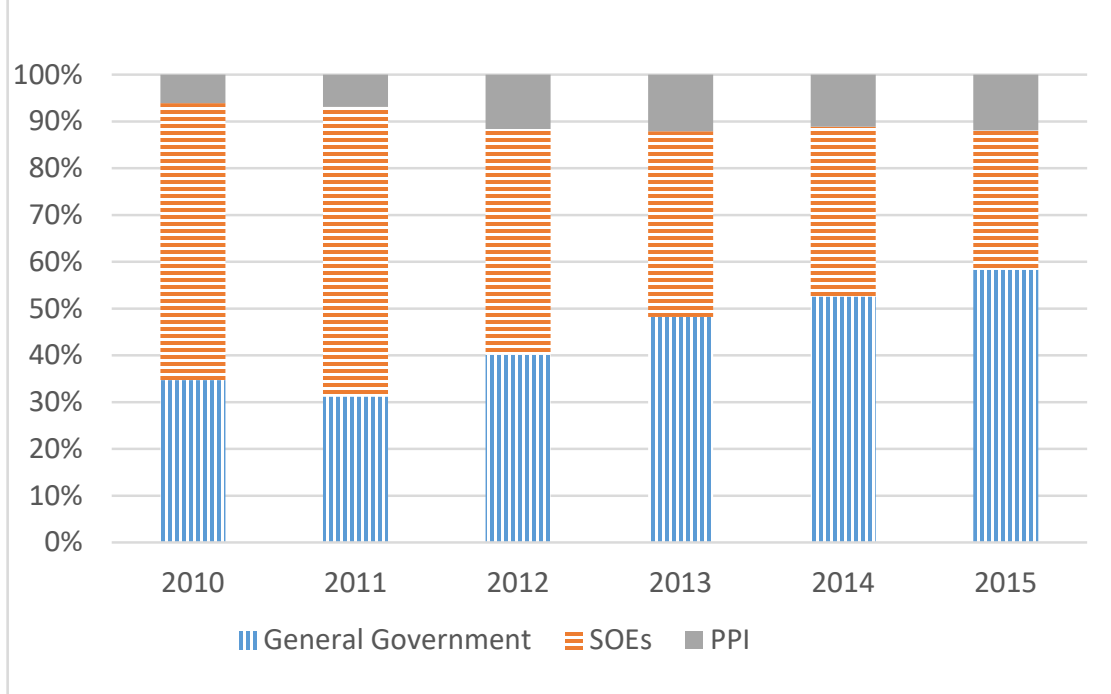

Figure 5 Breakdown of Infrastructure Investment in Indonesia by Investor Type, 2010-2015.

\section{Problems of the Belt and Road in Infrastructure Construction}

\subsection{Financing Demand is Large While the Number is Difficult to Meet}

Table 1 Estimated Infrastructure Investments and Gaps, 25 DMCs, 2016-2020(\$ billion in 2015 prices).

\begin{tabular}{|c|c|c|c|c|c|c|c|}
\hline \multirow[t]{2}{*}{ Country/Type } & \multirow{2}{*}{$\begin{array}{c}\text { Estimated } \\
\text { Current } \\
\text { Investment(2015) }\end{array}$} & \multicolumn{3}{|c|}{ Baseline Estimates } & \multicolumn{3}{|c|}{ Climate-adjusted Estimates } \\
\hline & & $\begin{array}{c}\text { Annual } \\
\text { Needs }\end{array}$ & Gap & $\begin{array}{c}\text { Gap(\% } \\
\text { of GDP) }\end{array}$ & $\begin{array}{l}\text { Annual } \\
\text { Needs }\end{array}$ & Gap & $\begin{array}{c}\text { Gap(\% } \\
\text { of GDP) }\end{array}$ \\
\hline Total (25) & 881 & 1211 & 330 & 1.7 & 1340 & 459 & 2.4 \\
\hline Total without PRC (24) & 195 & 457 & 262 & 4.3 & 308 & 308 & 5.0 \\
\hline $\begin{array}{c}\text { Selected Central Asia } \\
\text { Countries (3) }\end{array}$ & 6 & 11 & 5 & 2.3 & 7 & 7 & 3.1 \\
\hline $\begin{array}{l}\text { Selected South Asia } \\
\text { Countries (8) }\end{array}$ & 134 & 294 & 160 & 4.7 & 195 & 195 & 5.7 \\
\hline $\begin{array}{l}\text { Selected Southeast Asia } \\
\text { Countries (7) } \\
\end{array}$ & 55 & 147 & 92 & 3.8 & 102 & 102 & 4.1 \\
\hline $\begin{array}{l}\text { Selected Pacific Countries } \\
(5)\end{array}$ & 1 & 2 & 1 & 6.2 & 2 & 2 & 6.9 \\
\hline India & 118 & 230 & 112 & 4.1 & 144 & 144 & 5.3 \\
\hline Indonesia & 23 & 70 & 47 & 4.7 & 51 & 51 & 5.1 \\
\hline PRC & 686 & 753 & 68 & 0.5 & 151 & 151 & 1.2 \\
\hline
\end{tabular}

The World Bank and the Asian Development Bank (ADB) estimated the financing gap of 25 
developing countries in Asia, the current total investment of 25 countries was $\$ 881$ billion and for keeping the Baseline(Baseline Estimates) and adapting climate(Climate-adjusted Estimates), annual financing needs to be $\$ 2551$ billion, There exist \$1670 billion gap. And China's gap up to \$219 billion, accounting for $1.7 \%$ of GDP, the remained 24 countries' gap is $\$ 570$ billion, accounting for 9.3\% of GDP. Follow this, both China and other countries along the" Belt and Road" also have large demand in infrastructure financing, the gap is huge and the total demend is difficult to meet. (Table 1)

\subsection{Imbalance between Countries and Regions}

Due to the political, economic, cultural, historical and other factors are different, the levels of economic development are not same in different countries also, the infrastructure financing exsit obviously imbalance [2]. Imbalance of one country's GDP can reflects the imbalance in infrastructure financing from one side, the per capita GDP of Poland in 2015 was \$12494.47, while India is only $\$ 1581.59$. And according to statistical data: Polish’s infrastructure financing was $\$ 4.42$ billion in 2015, while India was only $\$ 1.93$ billion. (Figure 6, Figure 7)

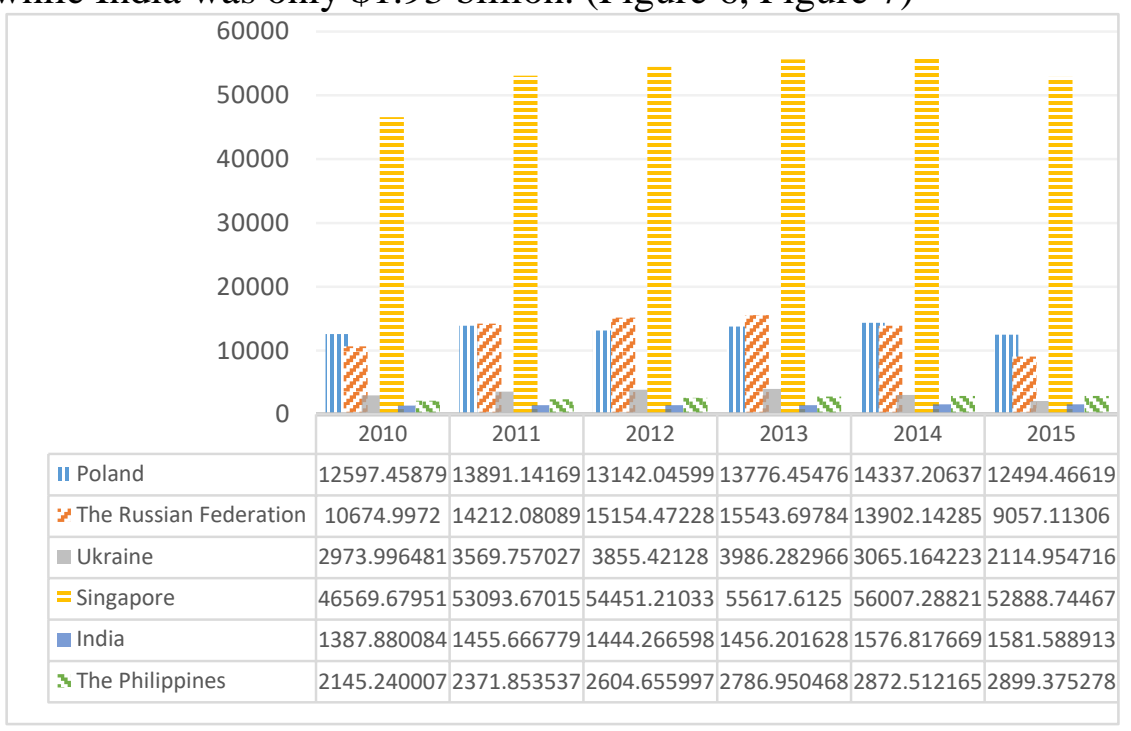

Figure 6 Per capita GDP in some countries (\$hundred million).

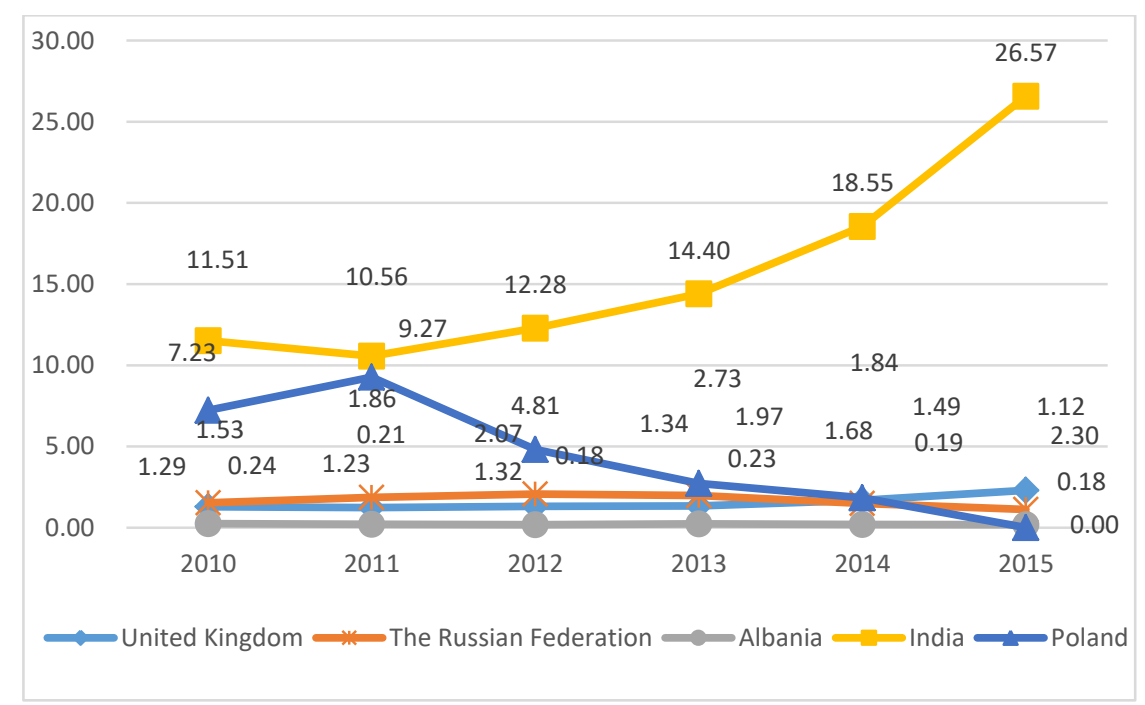

Figure 7 Some countries' transport infrastructure financing situation (€billion). 


\subsection{Private Capital Investment can be Further Strengthened}

Infrastructure as public products, with non-profit feature, there are few profit departments will invest and build infrastructure. Take China's infrastructure financing in 2015 for example, the private holdings in education financing were $17.02 \%$. In fact, the highest proportion was $25.41 \%$ in private holdings of the five types of infrastructure financing (Table 2, Figure 9), so investment of private capital need to be further strengthened.

Table 2 China's Partial Infrastructure Financing in 2015(¥hundred million).

\begin{tabular}{|c|c|c|c|c|c|c|}
\hline Name/Type & Inland Inv & $\begin{array}{c}\text { HK,MO } \\
\text { and TW } \\
\text { Inv }\end{array}$ & $\begin{array}{c}\text { Foreign } \\
\text { Inv }\end{array}$ & SOH & CH & PH \\
\hline $\begin{array}{c}\text { Transport, Storage and } \\
\text { Postal Services }\end{array}$ & 48320.1 & 268.3 & 386.5 & 36114.5 & 1255 & 8887.3 \\
\hline $\begin{array}{c}\text { Water, Environment and } \\
\text { Public Facilities } \\
\text { Management }\end{array}$ & 55479.1 & 105.1 & 94.8 & 41047.3 & 3939 & 6922.9 \\
\hline Education & 7676.3 & 31.8 & 15.1 & 5569.7 & 381.2 & 1232.2 \\
\hline Health and Social Work & 5142.2 & 25.6 & 7 & 3131.2 & 310.2 & 1314.8 \\
\hline $\begin{array}{c}\text { Public administration,Social } \\
\text { Security and Organization }\end{array}$ & 7833.6 & 6.3 & 11.1 & 5710.6 & 1066.7 & 374.5 \\
\hline
\end{tabular}

\subsection{Insufficient Cooperation between Regions}

In 2015, foreign investment of core infrastrucure in China accounted for $0.14 \%-0.79 \%$ of the total financing, while the domestic capital accounted for more than 99.30\% (Table 2, Figure 9). There had a serious imbalance in internal and external financing, and the degree of cooperation among the countries along the line should be further strengthened.

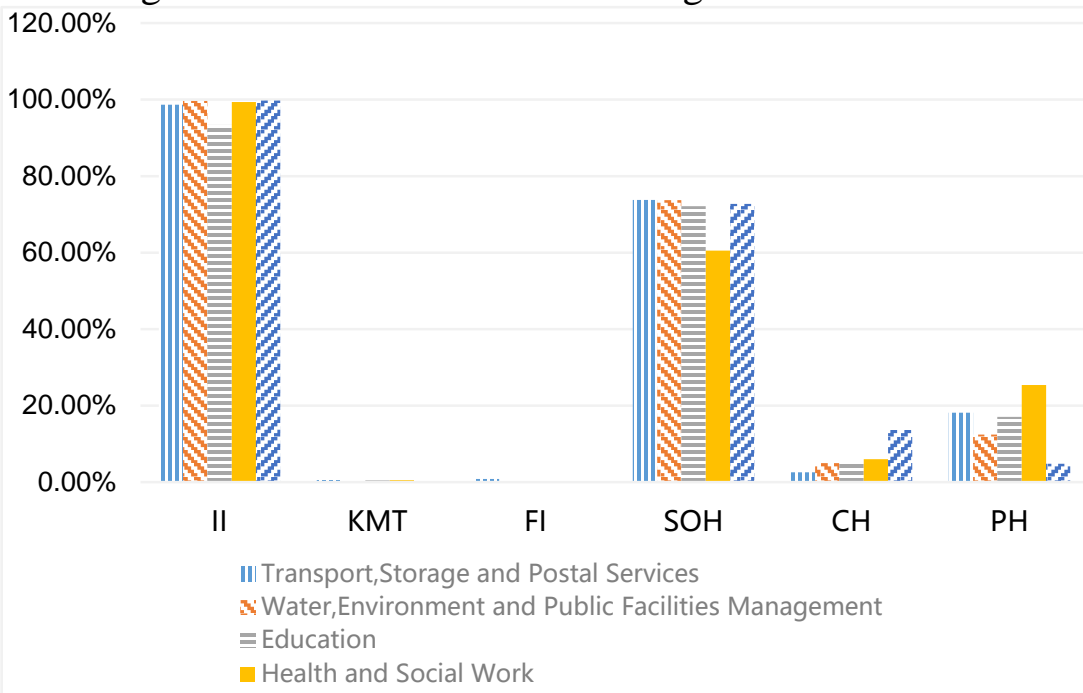

Figure 8 China's infrastructure investment as\% of Total in 2015. 


\section{Estimation of Financing Scale of the Belt and Road's Infrastructure}

\subsection{Overall Estimation of Financing Scale}

According to two factors-baseline and climate-adjusted, the United Nations (UN) (2015 Revision of World Population Prospects [3] and the Asian Development Bank (ADB) discussed the infrastructure costs of maintaining Baseline and adapting weather changing. Based on the projections of GDP growth, population growth and per capita GDP in 2030 estimated Asia and the Pacific region should invest $\$ 48717$ billion, annual investment is $\$ 3247$ billion, accounting for about $11.0 \%$ of GDP (Figure 9, Table 3).

Table 3 Estimated Infrastructure Investment Needs by Region, 45 DMCs, 2016-2030(\$billion in 2015 prices).

\begin{tabular}{|c|c|c|c|c|c|c|c|c|c|}
\hline \multirow[b]{2}{*}{ Region/Subregion } & \multirow[b]{2}{*}{$\begin{array}{c}\text { Projected } \\
\text { Annual } \\
\text { GDP } \\
\text { Growth }\end{array}$} & \multirow[b]{2}{*}{$\begin{array}{c}2030 \text { UN } \\
\text { Population } \\
\text { Projection } \\
\text { (billion) }\end{array}$} & \multirow{2}{*}{\begin{tabular}{|c|}
2030 \\
Projected \\
GDP Per \\
Capita \\
$(2015 \$)$
\end{tabular}} & \multicolumn{3}{|c|}{ Baseline Estimates } & \multicolumn{3}{|c|}{ Climate-adjusted Estimates } \\
\hline & & & & $\begin{array}{c}\text { Investment } \\
\text { Needs }\end{array}$ & $\begin{array}{l}\text { Annual } \\
\text { Average }\end{array}$ & \begin{tabular}{|c|} 
Investment \\
Needs \\
as \% of \\
GDP \\
\end{tabular} & $\begin{array}{l}\text { Investment } \\
\text { Needs }\end{array}$ & $\begin{array}{l}\text { Annual } \\
\text { Average }\end{array}$ & \begin{tabular}{|c|} 
Investment \\
Needs \\
as \% of \\
GDP \\
\end{tabular} \\
\hline Central Asia & 3.1 & 0.096 & 6202 & 492 & 33 & 6.8 & 565 & 38 & 7.8 \\
\hline East Asia & 5.1 & 1.503 & 18602 & 13781 & 919 & 4.5 & 16062 & 1071 & 5.2 \\
\hline South Asia & 6.5 & 2.059 & 3446 & 5477 & 365 & 7.6 & 6347 & 423 & 8.8 \\
\hline Southeast Asia & 5.1 & 0.723 & 7040 & 2759 & 184 & 5.0 & 3147 & 210 & 5.7 \\
\hline The Pacific & 3.1 & 0.014 & 2889 & 42 & 3 & 8.2 & 46 & 3.1 & 9.1 \\
\hline $\begin{array}{c}\text { Asia and the } \\
\text { Pacific }\end{array}$ & 5.3 & 4.396 & 9277 & 22551 & 1503 & 5.1 & 26166 & 1744 & 5.9 \\
\hline
\end{tabular}

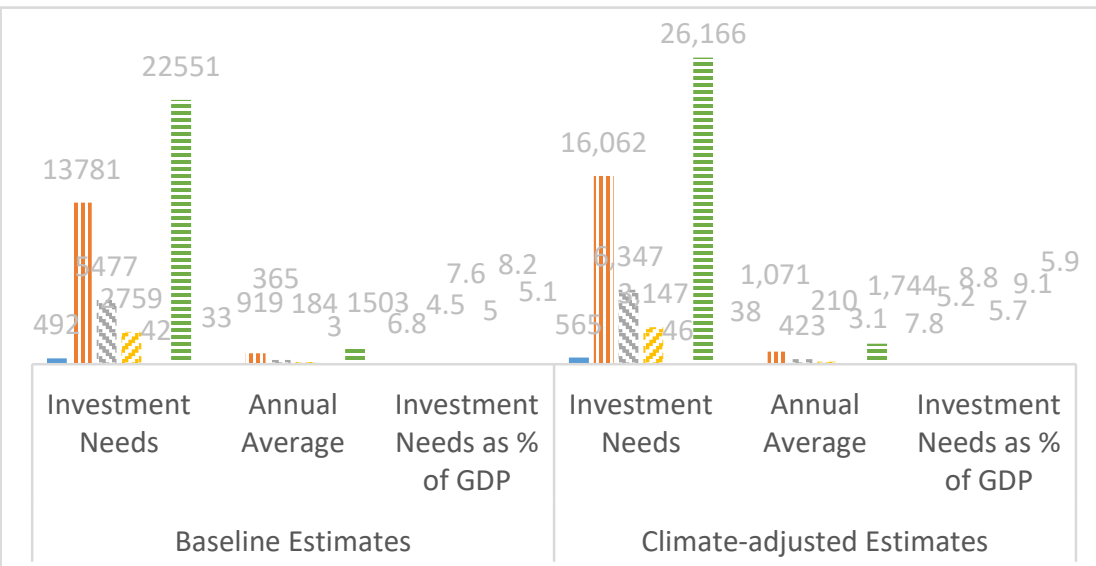

- Central Asia !!! East Asia $\mathbf{x}$ South Asia 2 Southeast Asia $\square$ The Pacific $\equiv$ Asia and the Pacific

Figure 9 Estimated Infrastructure Investment Needs by Region, 2016-2030(\$ billion).

\subsection{Estimation of Financing Scale for Some Core Infrastructure Construction}

The United Nations (2015 Revision of World Population Prospects) and the Asian Development Bank (ADB) estimated the scale of some core infrastructure financing, such as \$11.69 trillion should be invested in energy sector from 2016 to 2030, \$7790 billion every year, accounting for $51.8 \%$ of gross assets. In addition, the other three items of traffic are estimated also (Figure 10, Figure 11). 


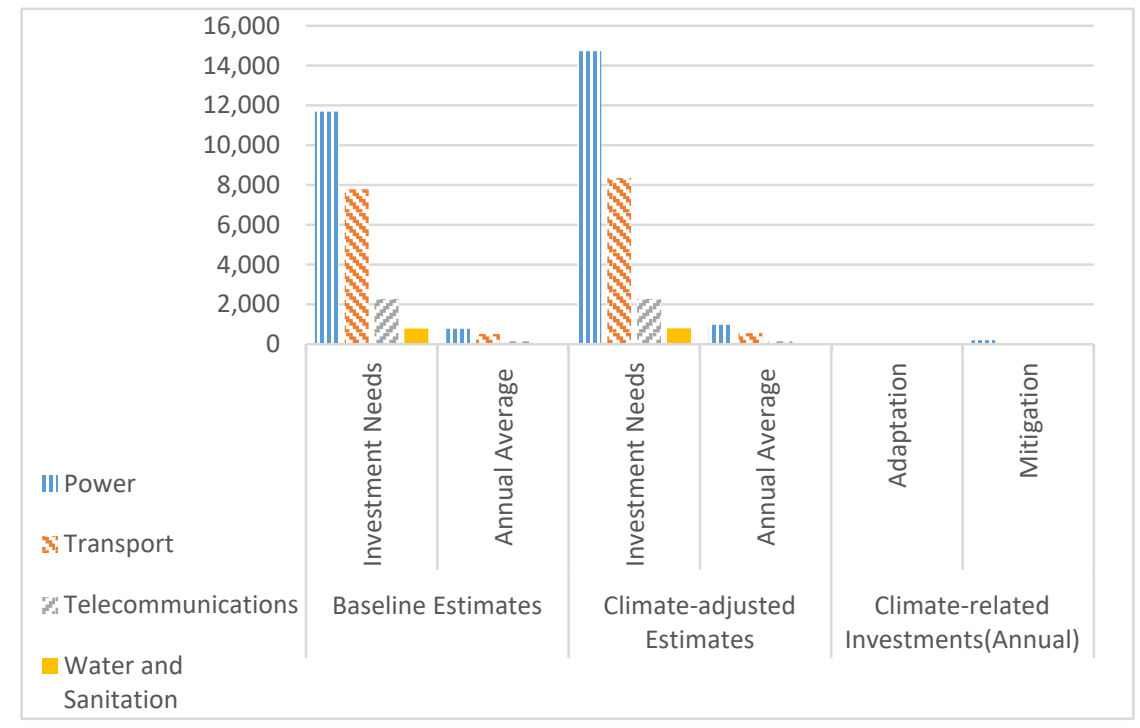

Figure 10 Infrastructure Investment Needs by Sector, 2016-2030(\$billion).

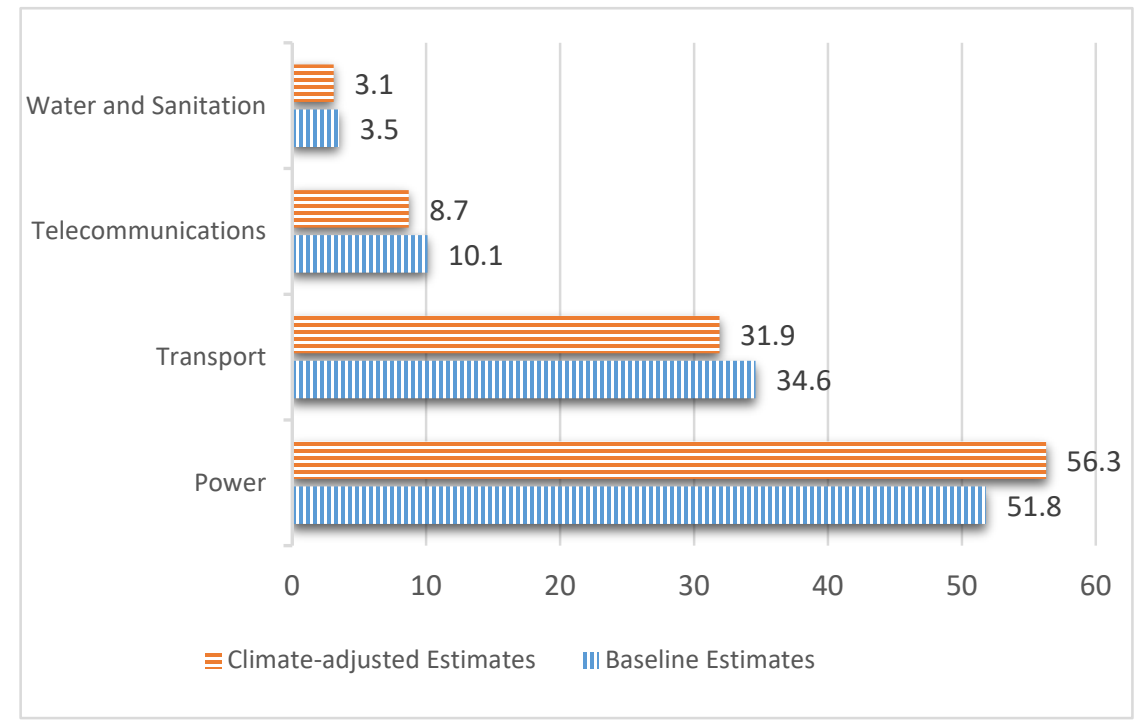

Figure 11 Some Infrastructure Investment Needs as \% of Total.

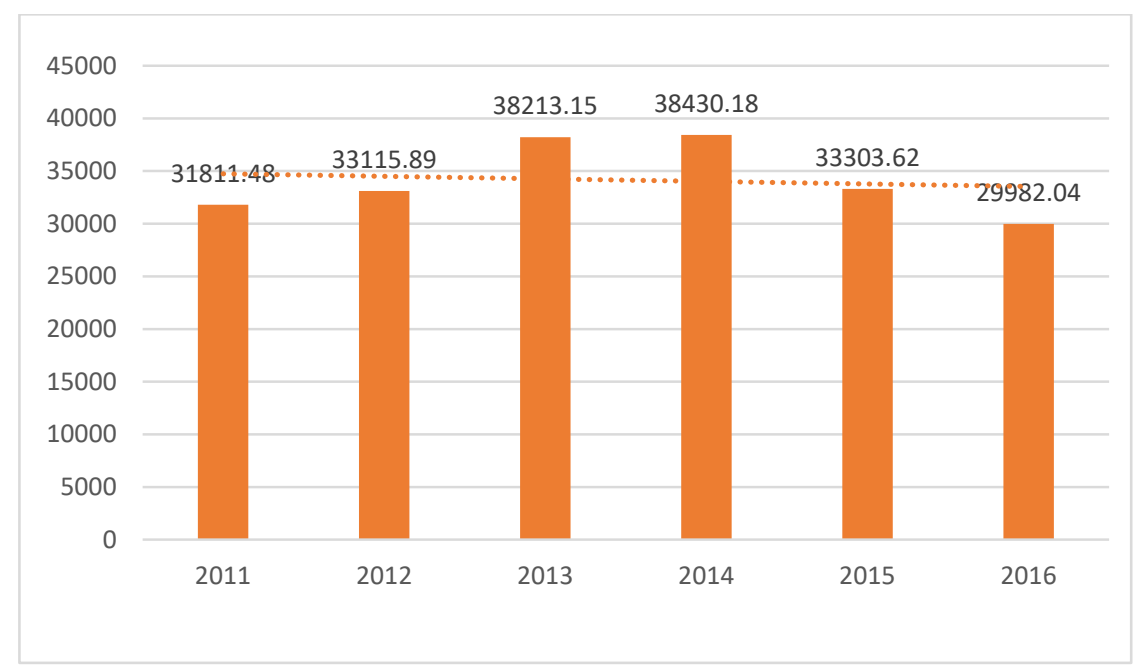

Figure 12 China 's Foreign Exchange Reserves(\$hundred million). 


\section{Suggestions for the Belt and Road Infrastructure Constructions}

\subsection{Play the "Capital Supply Station" Role and Make Full Use of Foreign Exchange Reserves}

There are many countries where the foreign exchange reserves is full along The Belt and Road. Such as China, although the amount of foreign exchange reserves has declined slightly in the past four years, the amount of foreign exchange in 2016 is still \$3.0 trillion (Figure 12). At the same time, some of the countries along the line are lacking in foreign exchange reserves and lack of funds for infrastructure, such as Bangladesh. The high reserve countries will avoid the risk of the exchange rate and the low reserve countries will meet the infrastructure needs ,if playing the role of "fund replenishment station" achieve the balance of all countries' foreign exchange and the goal of funds' accommodation[4].

\subsection{Establish a Perfect Credit System to Eliminate the Credibility of the Deficit}

Due to the differences in economy, culture, political stability and other conditions is different, the more than 60 countries along The Belt and Road have different credit condition. There are 4 countries ranking "A" and 6 countries ranking "B" in the solvency and sovereign credit rating of 10 Central and Eastern European countries. Therefore, establishing a perfect credit system, avoiding credit risk and eliminating credit deficit in international cooperation is significant.

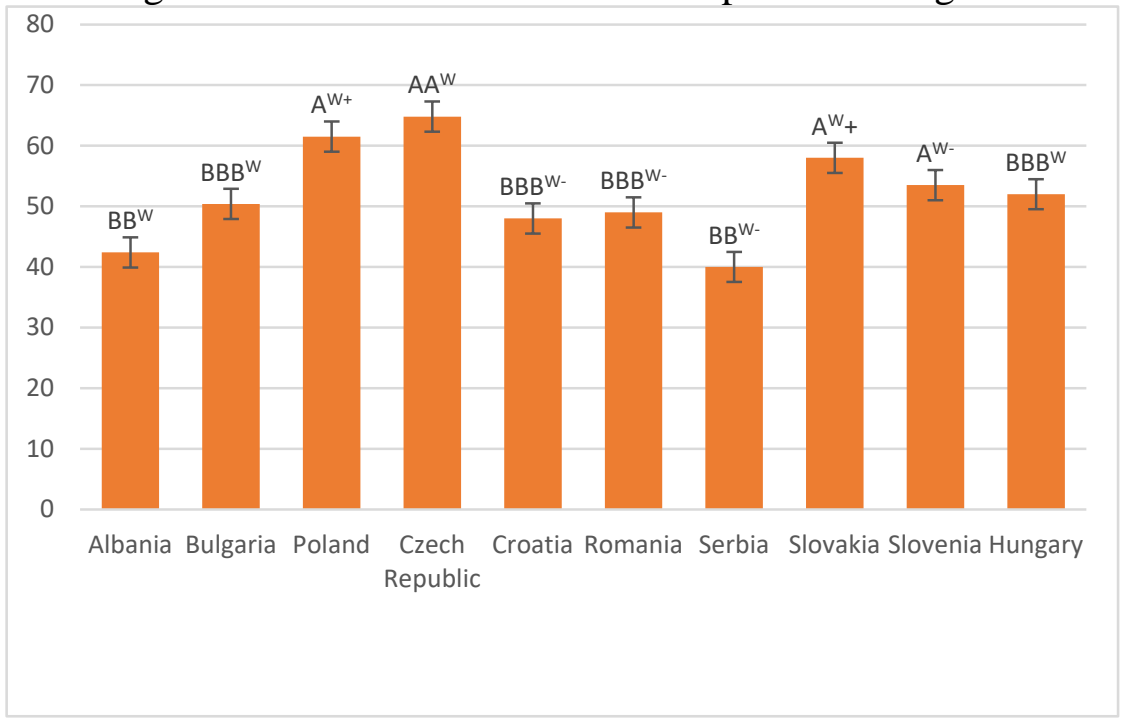

Figure 1310 Central and Eastern European countries sovereign credit level in 2016

\subsection{Public and Private Sectors Work Together to Adopt a Variety of Financing Modes}

Table 2 and Figure 3 shows that the private sector plays a small role in infrastructure financing in China, the number of average financing accounted for about $10 \%$ Tfor total, while the public sector financing up to $90 \%$, almost "a dominance". So mobilizing private sector's enthusiasm, making the public and private departments work together is a "short cut" to solve problems. Public and private sector cooperation methods mainly include four modes-PPP, BOT, TOT, and RCP (Table 4), the four modes have their own advantages and disadvantages [8], so four patterns should be combined, making best use of thier strengths and bypass thier weaknesses. 
Table 4 Public-private sector cooperation models.

\begin{tabular}{|c|c|c|}
\hline Types & The explantion of name & Features \\
\hline \multirow[t]{2}{*}{ PPP } & \multirow[t]{2}{*}{ public-private-partnership } & $\begin{array}{l}\text { Government and the private sector cooperation based } \\
\text { on concession agreements }\end{array}$ \\
\hline & & Sharing interests, sharing risks, full cooperation \\
\hline \multirow{4}{*}{ BOT } & \multirow{4}{*}{ build-operate-transfer } & Government give the private sector some concession \\
\hline & & $\begin{array}{l}\text { The private sector finance, construct, manage and run } \\
\text { infrastructure }\end{array}$ \\
\hline & & The private sector can charge the user \\
\hline & & Expired ownership free of charge to the government \\
\hline \multirow{3}{*}{ TOT } & \multirow{3}{*}{ transfer-operate-transfer } & $\begin{array}{l}\text { Government construct infrasture, and paid to the } \\
\text { private sector }\end{array}$ \\
\hline & & $\begin{array}{l}\text { When the contract expires, the private sector return } \\
\text { ownership to government for free }\end{array}$ \\
\hline & & Suitable for business projects \\
\hline \multirow{4}{*}{ RCP } & \multirow{4}{*}{ resource-compensation-project } & $\begin{array}{l}\text { Government empower enterprises to build, operate and } \\
\text { maintain infrastructure }\end{array}$ \\
\hline & & Enterprises can charge users \\
\hline & & $\begin{array}{l}\text { When the contract expires, the private sector return } \\
\text { ownership to government for free }\end{array}$ \\
\hline & & $\begin{array}{l}\text { Government transfer resources to enterprises as a } \\
\text { compensation }\end{array}$ \\
\hline
\end{tabular}

\subsection{To Promote the Internationalization of the RMB and Eliminate Exchange Rate Risk}

At present, capital dealings of the countries along The Belt and Road settle in dollars. So they may face the risk of exchange rate loss. Because of the large scale of infrastructure financing flowing, many infrastructure projects and frequent capital exchanges, the risk of exchange rate loss will cause huge losses [6]. Because RMB is the world's fifth largest payment currency, China is also the "leader" of the Asian Infrastructure Investment Bank and the largest shareholder, RMB has the conditions of wild using in regions (Figure 13). The risk of exchange rate loss can be reduced and the efficiency and adequacy of infrastructure financing can be improved, if we promote RMB in the regions of the Belt and Road and internationlise it. Besides, we can catch the opportunity of RMB internationlization to strengthen national unity and promote the overall development. 


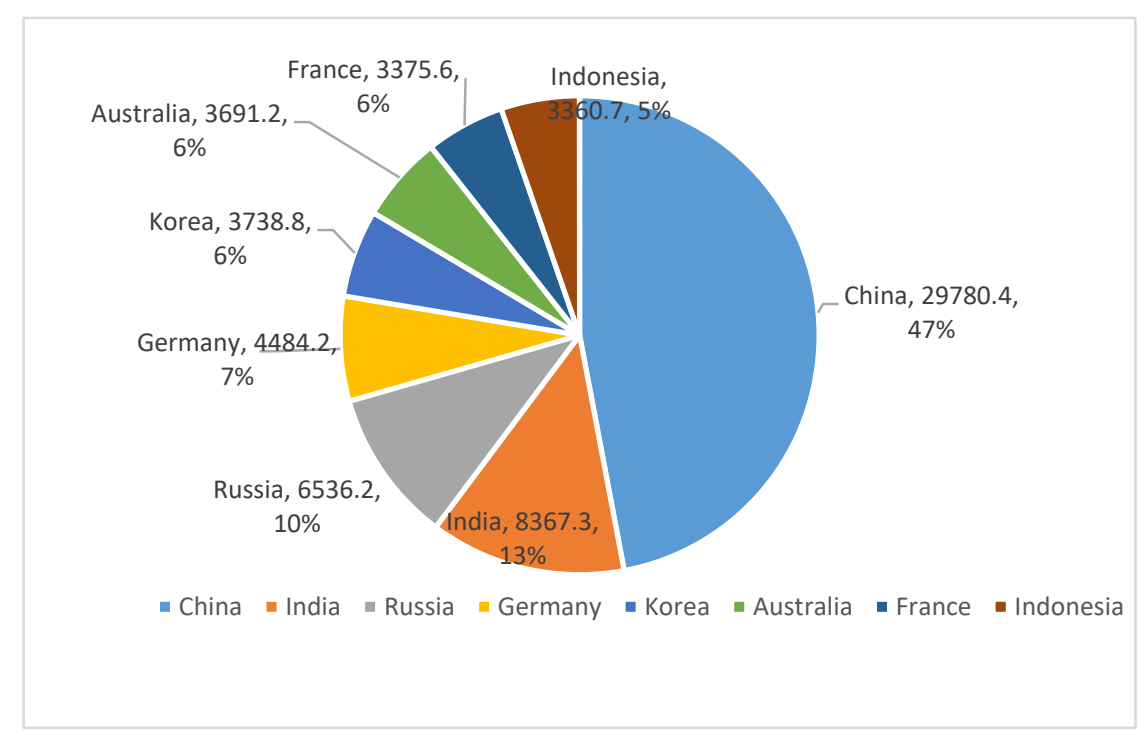

Figure 14 Investment Situation of ADB Shareholders (\$million).

\section{Conclusions}

Since the Belt and Road was put forward, 6 Silk Roads developed rapidly and related infrastructure construction made gratifying achievements. However, there are also problems, such as a huge financing gap, imbalanced investment and limited cooperation. To this end, we should play the "Capital Supply Station "role and make full use of foreign exchange reserves; establish a perfect credit system to eliminate the credibility of the deficit; public and private sector work together to adopt various financing models and internationalise RMB to eliminate exchange rate risk and so on.

\section{Acknowledgements}

In the end, I want to say thanks for all people that helped me, especially my directed teacher and my partner writer, besides, supporting funds need to be mentioned.

\section{References}

[1] Sun, Y. and Wu, H.Y. (2017) Establishment of Infrastructure Demand and Economic Decision of Investment and Financing in Silk Road Economic Belt. Economic Issues, 1(3), 92-97.

[2] Yuan, J. (2016) “The Belt and Road” Infrastructure Funding Demand and Investment and Financing Model. International Trade, 1(5), 52-56.

[3] T. Nakao. (2016) Meeting Asia’s Infrastructure Needs, Asian Development Bank. Manila, 1st edition.

[4] Huo, J.G. (2016) New Mode of Investment and Financing in International Infrastructure. International Economic Cooperation, 1(4), 4-9.

[5] Guo, G.X., Zhao, Y. and Wu, H.M. (2016) The Choice of the Optimal Financing Mode for China's "Going Out" Enterprises-Based on the Perspective of Information Economics, Financial Research. 1(8), 111-125.

[6] Yao, L. and Yao, W.X.( 2016) A Study on the Policy Effect of Gradual Expansion of Margin - Based on Multi-period DID Model and Hausman Test. International Finance Research, 1(5), 85-95. 